Pobrane z czasopisma Studia Iuridica Lublinensia http://studiaiuridica.umcs.pl Data: 26/04/2023 10:28:14

Reports Studia Iuridica Lublinensia vol. XXVII, 4, 2018 DOI: 10.17951/sil.2018.27.4.173-176

Agata Lipińska

Uniwersytet Marii Curie-Skłodowskiej w Lublinie

ORCID: 0000-0002-7739-9537

agata.lipinska@poczta.umcs.lublin.pl

\title{
Sprawozdanie z Ogólnopolskiej Konferencji Naukowej „Środki prawne ograniczające unikanie i uchylanie się od opodatkowania", Lublin, 20 kwietnia 2018 r.
}

Report from the National Scientific Conference "Legal Measures Restricting Avoidance and Tax Evasion", Lublin, 20 April 2018

W dniu 20 kwietnia 2018 r. na Wydziale Prawa i Administracji Uniwersytetu Marii Curie-Skłodowskiej w Lublinie odbyła się Ogólnopolska Konferencja Naukowa „Środki prawne ograniczające unikanie i uchylanie się od opodatkowania”. Wydarzenie zostało zorganizowane przez Studenckie Koło Naukowe Prawa Podatkowego UMCS pod patronatem merytorycznym Katedry Prawa Finansowego WPiA UMCS. Konferencja była skierowana do studentów i młodych pracowników nauki. Patronat honorowy nad wydarzeniem objęli m.in. Naczelny Sąd Administracyjny, Polska Izba Biegłych Rewidentów, Krajowa Rada Doradców Podatkowych, Dyrektor Izby Administracji Skarbowej w Lublinie, Wydawnictwo Sejmowe, Pismo Adwokatury Polskiej „Palestra”, Czasopismo Krajowej Reprezentacji Samorządowych Kolegiów Odwoławczych „CASUS” oraz KPMG Polska. Natomiast w gronie patronów medialnych znaleźli się: dziennik „Rzeczpospolita”, TVP Lublin, Radio Centrum oraz portal KarierawFinansach.pl.

Zjawisko unikania i uchylania się od opodatkowania stanowi obecnie jeden z istotnych problemów stojących przed władzami państwowymi, dlatego krajowy i międzynarodowy porządek prawny wyposażono w nowe rozwiązania istotnie zmieniające system podatkowy. Wiąże się z tym potrzeba pogłębionych badań nad środkami prawnymi ograniczającymi unikanie i uchylanie się od opodatkowania. Ideą konferencji była zatem analiza regulacji prowadzących do zapewnienia jak największej przejrzystości czynności prawnych w obrocie gospodarczym, a jed- 
nocześnie zwiększenia skuteczności działania organów podatkowych. Aktualność podjętej tematyki zaowocowała dużym zainteresowaniem konferencją, która ostatecznie zebrała prawie 30 prelegentów z siedmiu ośrodków uniwersyteckich.

Uroczystego otwarcia konferencji dokonał prof. A. Hanusz, Kierownik Katedry Prawa Finansowego UMCS oraz sędzia Naczelnego Sądu Administracyjnego, który powitał zarówno prelegentów, jak i licznie zgromadzonych gości. W konferencji udział wzięli także pracownicy Katedry Prawa Finansowego WPiA UMCS: dr hab. A. Niezgoda, dr P. Szczęśniak, mgr K. Cień i mgr T. Woźniak oraz członkowie zarządu Oddziału Lubelskiego Krajowej Izby Doradców Podatkowych.

Obrady odbyły się w ramach trzech sesji tematycznych. Pierwsza z nich była moderowana przez dr. P. Szczęśniaka, natomiast referat inaugurujący obrady wygłosiła mgr M. Zwierz (Uniwersytet Warszawski). Referentka dokonała analizy prawno-porównawczej klauzuli obejścia prawa podatkowego na tle analogicznych konstrukcji prawnych wypracowanych w innych państwach europejskich. Co istotne, uwzględniła również standardy w zakresie ich stosowania, w tym istnienie odpowiednich mechanizmów ochrony obywateli przed nieuprawnioną i nieuzasadnioną ingerencją w sferę ich praw. Następnie głos zabrała mgr M. Dąbrowska (Uniwersytet Łódzki), która zaprezentowała referat zatytułowany „Interpretacja indywidualna a klauzula o unikaniu opodatkowania”. Autorka poruszyła problem dopuszczalności wydania interpretacji przepisów prawa podatkowego $\mathrm{w}$ indywidualnej sprawie, której przedmiotem miałby być zakres ochrony wynikającej z poprzednio udzielonej danemu wnioskodawcy interpretacji.

Następną referentką była mgr T. Sławińska-Choryło (Polska Akademia Nauk). Wystąpienie dotyczyło systemu SENT, czyli elektronicznego systemu służącego monitorowaniu przemieszczenia się towarów. Konstrukcja systemu SENT jest zbliżona do już funkcjonującego Systemu Przemieszczania oraz Nadzoru Wyrobów Akcyzowych (systemu EMCS). Prelegentka zwróciła uwagę na konsekwencje funkcjonowania obok siebie tych dwóch systemów. Negatywnym skutkiem przyjęcia takiego rozwiązania jest zmniejszenie skuteczności tych systemów w zakresie efektywnego poboru podatków.

Z kolei K. Jagocha (Uniwersytet Śląski) wygłosił referat poświęcony klauzuli przeciwko unikaniu opodatkowania. Referent opisał proces kształtowania się klauzuli w polskim ustawodawstwie, proces jej wprowadzenia oraz wpływ wstąpienia Polski do Unii Europejskiej. Stwierdził, że obecny kształt klauzuli w przepisach podatkowych doprowadza do obniżenia zaufania obywateli do państwa i stanowionego przez nie prawa.

Wystąpienie zamykające pierwszą sesję wygłosiła mgr A. Pazura (Polska Akademia Nauk). Dotyczyło ono instytucji prewspółczynnika w podatku od towarów i usług. Instytucja ta ma zastosowanie w sytuacji nabycia towarów i usług wykorzystywanych zarówno do celów wykonywanej przez podatnika działalności gospodarczej, jak i do celów innych niż działalność gospodarcza, z wyjątkiem 
celów osobistych, gdy przypisanie tych towarów i usług w całości do działalności gospodarczej podatnika nie jest możliwe. Kwotę podatku naliczonego oblicza się wówczas zgodnie ze sposobem określenia zakresu wykorzystywania nabywanych towarów i usług do celów działalności gospodarczej. Sposób określenia proporcji (tzw. prewspółczynnik) stanowi rozwiązanie ograniczające zjawisko unikania i uchylania się od opodatkowania. Referentka zaznaczyła, że metoda określania proporcji powinna jednak odpowiadać specyfice wykonywanej przez podatnika działalności i dokonywanych przez niego czynności prawnych.

Referat rozpoczynający drugą sesję, moderowaną przez mgr. K. Cienia, wygłosił mgr F. Biegun (Uniwersytet Jagielloński). Celem było przybliżenie genezy powstania klauzuli nadużycia prawa na gruncie podatku od towarów i usług jako konsekwencji obowiązywania zasady ogólnej zakazu nadużycia prawa Unii Europejskiej. Choć klauzula nadużycia prawa została wprowadzona do ustawy o podatku od towarów i usług w dniu 15 lipca 2016 r., normatywne zręby zasady zakazu stosowania nadużycia prawa istniały już w prawodawstwie unijnym oraz w orzecznictwie Trybunału Sprawiedliwości Unii Europejskiej.

M. Wróblewski (UMCS) wygłosił referat na temat obowiązku znakowania i barwienia paliw opałowych. Obowiązek ten ma przeciwdziałać wykorzystywaniu ich jako paliwa napędowego, co prowadzi do zastosowania niższej stawki podatkowej. Naruszenie warunków stosowania obniżonych stawek akcyzy może skutkować zastosowaniem zwyżek podatku, a więc podwyższonych stawek podatku akcyzowego.

Swoje referaty zaprezentowały także A. Zdybska (UMCS) oraz B. Zielińska-Rapacz (Uniwersytet Jagielloński). Pierwsza z nich omówiła tzw. pakiet paliwowy jako środek prawny uszczelniający system podatkowy w Polsce. W ocenie prelegentki rozwiązania wynikające z przepisów ustawy z dnia 7 lipca $2016 \mathrm{r}$. o zmianie ustawy o podatku od towarów i usług oraz niektórych innych ustaw skutecznie ograniczyły przestępstwa na rynku paliwowym, wykorzystujące mechanizmy wewnątrzwspólnotowych nabyć paliw realizowanych za pośrednictwem zarejestrowanych odbiorców. Natomiast celem wystąpienia B. Zielińskiej-Rapacz było w pierwszej kolejności objaśnienie genezy systemu wymiany informacji podatkowych w Polsce i Unii Europejskiej oraz mechanizmu funkcjonowania tego systemu, a także ocena jego znaczenia dla podatników. Prelegentka zwróciła uwagę uczestników konferencji na kwestię ryzyka związanego z daleko idącą ingerencją w sferę wymiany informacji podatkowych między państwami.

Referat K. Włodarczyk (UMCS) otworzył ostatnią sesję konferencji, moderowaną przez mgr. T. Woźniaka. Prelegentka omówiła zaświadczenie o rozliczeniu kontrahenta. Autorka podkreśliła, że jednym ze sposobów eliminacji (a przynajmniej ograniczenia) ryzyka zawieranych umów jest możliwość sprawdzania wiarygodności przedsiębiorcy, w tym jego rzetelności w zakresie rozliczeń podatkowych. Następnie A. Nowak (UMCS) przedstawiła referat zatytułowany „Outsourcing pracowniczy jako forma uchylania się od opodatkowania”. Uchylanie się od obo- 
wiązków pracodawcy jako płatnika w związku z wykorzystaniem outsourcingu pracowniczego jest coraz częstszym zjawiskiem. Dotyczy ono przede wszystkim nieuiszczania zaliczek na podatek dochodowy osób uzyskujących przychody z pracy świadczonej na rzecz danego pracodawcy. Prelegentka zauważyła, że przedmiotem sporów dotyczących outsourcingu pracowniczego jest zazwyczaj ocena skuteczności zawarcia „umów outsourcingu pracowniczego” oraz nieuznawanie się ani przez pracodawcę zbywającego zakład pracy lub jego część, ani przez nowego pracodawcę za podmiot zobowiązany do wypełniania obowiązków płatnika.

Z kolei W. Mirytiuk (UMCS) poruszyła kwestię aktualnych problemów dotyczących funkcjonowania w Polsce podatkowych grup kapitałowych. Autorka skupiła się na nowelizacji ustawy o podatku dochodowym od osób prawnych, która weszła w życie w dniu 1 stycznia 2018 r. Nowelizacja ta wprowadziła szereg zmian zmierzających do ograniczenia naruszeń oraz uszczelnienia systemu podatkowego.

Ostatnie dwa referaty konferencji przedstawili K. Matysiak (Uniwersytet Warszawski) oraz mgr K. Wójcik i mgr M. Ryłko (Uniwersytet Warszawski). Pierwsza z wymienionych odniosła się do kwestii dokumentacji podatkowej cen transferowych. Podczas wystąpienia wyjaśniła okoliczności związane z koniecznością sporządzenia takiej dokumentacji, wskazała elementy, które powinna zawierać oraz opisała sposób jej przedłożenia. Natomiast wystąpienie K. Wójcik i M. Ryłko było poświęcone podatkowi od nieruchomości w kontekście pojęcia budynku i budowli związanej lub zajętej na potrzeby prowadzenia działalności gospodarczej w świetle najnowszego orzecznictwa Trybunału Konstytucyjnego i Naczelnego Sądu Administracyjnego.

Należy zaznaczyć, że wystąpienia uczestników konferencji były asumptem do ciekawych dyskusji, toczących się zarówno w trakcie, jak i po poszczególnych sesjach.

Ze względu na zainteresowanie konferencją „Środki prawne ograniczające unikanie i uchylanie się od opodatkowania" oraz różnorodność poruszanej przez prelegentów tematyki organizatorzy podjęli starania o przygotowanie publikacji pokonferencyjnej. Artykuły naukowe, złożone przez uczestników konferencji, zostaną wydane nakładem Wydawnictwa Uniwersytetu Marii Curie-Skłodowskiej w monografii będącej podsumowaniem obrad. 